This paper advances the case for the abolition of rent, interest, and profit. Rent, interest, and profit often appear perfectly normal for those living and working in capitalist economies, and are made to look normal in capitalist economics, the media, the capitalist state, and more generally by those who benefit from these forms of income without working. Because of the basic systemic violence on which they rest, however, rent, interest, and profit also produce resentment, criticism, refusal, and, at times, organised resistance. Systematic political organisation against the practices of rent, interest, and profit has been and should still be at the basis of Left politics. By this same measure, almost all so-called 'Left' parliamentary parties in Aotearoa New Zealand and elsewhere have given up the game. What is developed here is not another lament about what has been lost. Rather, this paper seeks to give some conceptual clarity to the need to organise politically, with a clear intent of victory, against rent, interest, and profit. 


\section{Rent, Interest, Profit}

\section{CAMPBELL JONES}

Rent, interest, and profit name three of the most important forms of economic exploitation today. ${ }^{1}$ They overlap and intersect with one another and have common roots in the exploitation of nature, collective human capacities, and waged and unwaged labour. Rent, interest, and profit each have their own dynamics. They each can vary in their rate of exploitation and in the extent of struggle they generate. This struggle plays out in a contest between the relative capacity of the recipients of rent, interest, and profit and those from whom they are extracted to exert their will. At base, the extent of rent, interest, and profit, and the extent to which these practices are taken to be normal and acceptable, is the result of the unequal distribution of resources and power. They arise from, and are inexplicable without, differential access to land, housing, or other assets (rent), money in the

1 I would like to thank the two anonymous reviewers for their many valuable suggestions for development of this paper, and Jack Foster for his patience, encouragement, useful comments, and attention to detail in the process of revision. Thanks also to Nathalie Jaques, Anna-Maria Murtola, and Shannon Walsh for their always insightful and incisive critiques of earlier versions of this paper. Thanks to students on my Fantasies of Finance course at the University of Auckland, in which many ideas in this paper developed over the past seven years. Thanks also to Catherine Cumming and Shanti Daellenbach, fellow travellers for so long, who both completed exceptional theses earlier this year, for your inspiring work on finance. 
form of money capital (interest), and control over the instruments and means of production (profit).

Even if discussion of these forms of exploitation has been largely suppressed in parliamentary politics today, one of the contentions of this paper is that we need to be reminded of the deep roots of opposition to rent, interest, and profit in the tradition of the Left. This opposition runs across progressive liberalism and social democracy through to the socialist, anarchist, and communist Left. Rent, interest, and profit form something of an 'unholy trinity' that is characteristic of the capitalist mode of production. ${ }^{2}$ I do not seek here to reduce this trinity to one founding factor on which they all ultimately rest. However, this is not to say that they are in any way separable from one another. In practical terms, for instance, simply raising wages without any mechanism for controlling rent will do little to improve the condition of working people. Nevertheless, while unified by an underlying logic and the fact that all three must be abolished, each has its own specific dynamic.

Rent, interest, and profit are important not only because they name economic exploitation, but because they always have been and always can be contested. The evisceration of the parliamentary Left in Aotearoa New Zealand over the past 40 years is a well-known tale, and several options have recently been tabled for its renewal. ${ }^{3}$ Some of the most important accounts of the fall of the parliamentary Left over this time have emphasised the role played by a set of economic changes and economic logics, in particular the

2 The unholy trinity that is our object here clearly owes a great deal to, while also at some points departing from, the analysis that Marx developed of 'the trinity formula' throughout his work and in particular in Volume Three of Capital. The trinity formula is summarised in Chapter 48 of Volume Three in terms of the first trinity: 'capitalprofit (profit of enterprise plus interest), land-ground-rent, labour-wages', which under the capitalist mode of production takes the second form: 'capital-interest, land-ground-rent, labour-wages'. Karl Marx, Capital, A Critique of Political Economy: Volume Three, trans. David Fernbach (London: Penguin, 1981 [1894]), 953.

3 Among the social-democratic accounts of the fall of the Left and proposals for its renewal in Aotearoa New Zealand see, for example, Morgan Godfery, ed., The Interregnum: Rethinking New Zealand (Wellington: Bridget Williams Books, 2016); Max Harris, The New Zealand Project (Wellington: Bridget Williams Books, 2017); Max Rashbrooke, Government for the Public Good: The Surprising Science of Large-Scale Collective Action (Wellington: Bridget Williams Books, 2018). 
logic of capitalist economics. ${ }^{4}$ Over the last 40 years, the parliamentary Left has, by and large, joined the Right - the traditional defenders of arbitrary elite privilege - and abandoned or forgotten how to think about, let alone question, economic practices such as rent, interest, and profit. What remains of the parliamentary Left has generally come to take such practices as part and parcel of normal economic life. As a result, it has focused its energies on damage control and pain mitigation rather than head-on confrontation with these exploitative practices.

Politics in the proper sense of the word marks some actual difference and is grounded in the prospect of something new. Without this there is only governmental management and policing of the established order. ${ }^{5}$ Previously in this journal, I argued at length that the dispute between the Left and the Right over the value and nature of work is not a disagreement over a shared object, but rather involves a profound dispute between irreconcilably different understandings of work and working people. ${ }^{6}$ Left politics in the meaningful sense is grounded in a distinct understanding of the economic basis on which contemporary society stands. My argument in this paper is that any serious Left politics must maintain, at the very least, a profound suspicion towards the principles of rent, interest, and profit and must make concrete steps towards reining in these forms of economic exploitation, with their outright abolition as its ultimate horizon.

One of the challenges to saying anything meaningful about rent, interest, and profit is that these words are widely used but very rarely given much conceptual clarity in the discourse of economics. Because

4 Brian Easton, The Commercialisation of New Zealand (Auckland: Auckland University Press, 2013); Bruce Jesson, Only Their Purpose is Mad: The Money Men Take Over NZ (Palmerston North: Dunmore Press, 1999); Jane Kelsey, The New Zealand Experiment, Second Edition (Auckland: Auckland University Press, 1996); Brian Roper, Prosperity for All? Economic, Social and Political Change in New Zealand Since 1935 (Palmerston North: Dunmore Press, 2005).

5 Various versions of this argument have been made across the intellectual Left in recent years. We have made this case in relation to the realities of political organisation in Aotearoa New Zealand in Campbell Jones and Shannon Walsh, 'What is Political Organisation?' Economic and Social Research Aotearoa 2 (2017): 1-6.

6 Campbell Jones, 'The Value of Work and the Future of the Left,' Counterfutures 4 (2017): 137-165. 
of its prejudices, particularism, and provincialism, and the agents that it privileges, it should be blindingly clear that the overwhelmingly dominant form of economics today is capitalist economics. In academic forms of capitalist economics and in business reporting and the capitalist state, terms such as rent, interest, and profit are used in such a way that it is hard to see what they actually involve. A key part of this reactive strategy involves stripping out the actual social and political relationships on which rent, interest, and profit rest. And if the social consequences of rent, interest, and profit are acknowledged, then they are almost always uncoupled from these practices or are blamed on the inadequacies or failings of their victims. Capitalist economics seeks to exclude both the social content and the political consequences of rent, interest, and profit. This is not to say, by any stretch, that capitalist economics is politically neutral, but rather, that it neutralises or seeks to defuse the explosive social and political potential that is contained in such practices.

Rent, interest, and profit should be understood as examples of a broader reality in which basic ideas in economics can only meaningfully be understood in terms of the social relations they entail and in the forms of social struggle they enable or disable. This is neither a matter of bringing contestation or critique to these practices from outside, nor of 'politicising' economic practice. Rather, it involves making sense of the already existing contestation of rent, interest, and profit, something I will seek to show can be seen, among other places, on the rugby field. Whether such contestation involves minor discontent at the latest rent rise, shock at the latest bankprofit figures, or deeper and more organised political confrontation, a generalised incredulity at the world of finance in many quarters attests to a very real but often quietly spoken set of concerns with the very idea of rent, interest, and profit, and capitalist economics and finance as such. These challenges do not come out of thin air and are not the result of ignorance or incomplete schooling in the dark arts of finance. If such concerns and contestation are often presented disparagingly as the ravings of the financially illiterate, this must be seen for the political silencing that it is. Against this, and such politically motivated dismissals, it must be remembered that there is a long and wide history of disbelief, starting out 
from a basic sense that rent, interest, and profit might not in the end be either justifiable or just.

Directly confronting rent, interest, and profit speaks to the kind of politics of the Left that are needed in a time where finance capital is so central to economic, social, cultural, and political life. The ascendency of finance and processes of financialisation are key transformations that have played out over the past 50 years. ${ }^{7}$ The increased presence of finance and of its organs such as banks, financial institutions, and landlords is a painfully apparent and palpably real part of capitalist accumulation and the reorganisation of the world in the image of finance capital. ${ }^{8}$ This paper seeks to specify some elements of the kinds of Left politics that are needed in precisely this moment of finance ascendant, taking on these specific logics of rent, interest, and profit.

The paper treats rent, interest, and profit in turn, seeking to clarify for each the unique form of economic exploitation involved and the forms of contestation that accompany them. There is nothing normal or natural about rent, interest, or profit. They are infinitely open to human contestation and transformation. They change over time and so, even if

7 There is now an extensive academic analysis and critique of finance. The empirical case for the rise of finance and its function in the emergence of a distinct mode of accumulation is well-made by Greta Krippner, Capitalizing on Crisis: The Political Origins of the Rise of Finance (Massachusetts: Harvard University Press, 2011). Among the vast critical literature on finance see, for example, François Chesnais, Finance Capital Today (Leiden: Brill, 2018); Costas Lapavitsas, Profiting Without Producing: How Finance Exploits Us All (London: Verso, 2013). My own efforts in comprehending finance appear in condensed form in Campbell Jones, 'The World of Finance,' Diacritics 44, no. 3 (2016): 30-54. Various other aspects of the social, cultural, and political significance of finance are dealt with in Campbell Jones, 'Finance, University, Revolt,' Argos Aotearoa 1 (2014): 44-50; 'The Embers of Truth in the Ashes of Finance,' in The Global Financial Crisis and Educational Restructuring, eds., Michael Peters et al (New York: Peter Lang, 2015); 'John Key the Biofinancial Entrepreneur,' Kötuitui 11, no. 2 (2016): 89-103.

8 The financialisation of the New Zealand economy is documented in detail by Jane Kelsey, The FIRE Economy: New Zealand's Reckoning (Wellington: Bridget Williams Books, 2015). On the place of finance in the housing market in Aotearoa New Zealand and the planning process of Tāmaki Makaurau Auckland, see the important work of Shane Malva, 'The Immanent Ruin of the Auckland Housing Crisis: Social Resistance Against the Financialisation of Housing,' New Zealand Sociology 31, no. 6 
rent, interest, and profit are among the oldest sites of political struggle, today they offer themselves again as new and vitally important grounds for political contestation. I therefore turn in the final section to call for the abolition of these forms of exploitation. Abolition is not an impractical and forever receding horizon of the impossible; it is practically instantiated in a refusal of the violence of rent, interest, and profit, and reflects a concrete vision for political organisation.

\section{Rent}

For many people the most visible form of rent is the regular payment made in return for access to accommodation. Rent for accommodation is one of the basic forms of rent and often stands in for the concept as such. Today, in Aotearoa New Zealand, this form has an incredibly important presence, largely because of the historical shift that has in recent years seen the proportion of households living in rental accommodation increase from 23 percent in 1991 to 32 percent in 2015. ${ }^{9}$ Accommodation rent has also seen a massive increase in the amount paid in rent year-by-year. ${ }^{10}$ This has involved an increase in absolute terms and been accompanied by stagnant wages and thus an increase in the percentage of income that goes to paying accommodation rent, particularly for those on lower incomes. Average rents in cities like Auckland are now more than half of average income, and slightly less than that in other regions. ${ }^{11}$ This has widely been noted as creating a wider group and a generation of permanent renters. The

(2016): 10-33; Vanessa Cole, 'Why Landlords and Investors Love the Auckland Unitary Plan, and Why You Shouldn't,' Economic and Social Research Aotearoa 1 (2017): 1-13.

9 Statistics New Zealand, 'Dwelling and household trends: 1991-2015,' http:// archive.stats.govt.nz/browse_for_stats/population/estimates_and_projections/ dwellings-household-trends-1991-2015.aspx.

10 See, for example, the annual-rent statistics over the past 20 years provided by Harcourts: https://www.barfoot.co.nz/market-reports/2017/april/20-years.

11 Greg Nines, 'Rent Rises Outpacing Wage Growth in Auckland and Wellington but Canterbury Renters Are on the Pig's Back,' May 9, 2018, https://www.interest. co.nz/property/93618/rent-rises-outpacing-wage-growth-auckland-and-wellingtoncanterbury-renters-are-pigs. 
pressure on rental housing, rises in rents, and the difficulty of finding rental accommodation have created great suffering and concern about the supply and quality of housing. ${ }^{12}$

In terms of the sheer amounts of rents extracted, accommodation rent is a crucial social form. Accommodation rent is also socially and politically important because it is historically one of the oldest forms of economic exploitation. For this reason, accommodation rent casts light on the basic dynamics of rent as such. Across its forms, rent arises from a legally sanctioned relation of exclusion in which those excluded must pay for access. It only exists because of inequality of access, in which one group is able to claim for itself the right of exclusive possession of property. Rent is a tribute that one person or group pays to another in order to have access to something from which one could otherwise be excluded. Historically, then, payment of rent in return for access to places to live and sleep is conditional upon the process of monopolisation of land by landowners. To establish this as an ongoing practice involves the dispossession of people from their land and the ongoing threatened or actual exclusion of tenants from that land.

The historical forms of the extraction of rent have varied greatly, even if the principle remains relatively constant. Early rents were often collected in the form of 'taxes' extorted by force by agents of the feudal aristocracy from tenant farmers or peasants who lived on land claimed by the aristocracy. In Europe, rent relations were later formalised in the corvée system, whereby a certain number of days of tribute in the form of labour or military service were demanded each year from peasants living on the land of lords. Today, practices of rent extend and at the same time refine this logic of exclusion accompanied by payment-for-inclusion. While, historically, the violence of expulsion from land and forced payment of tribute were openly visible to both sides of the rent relation, with modern capitalist rent this violence is obscured behind the idea that rental contracts, like any other exchange of goods or services, are contracts freely entered into by equal subjects. In modern law and liberal political thought, rent relationships become

12 Shamubeel Eaqub and Selena Eaqub, Generation Rent (Wellington: Bridget Williams Books, 2015); Malva, 'The Immanent Ruin of the Auckland Housing Crisis.' 
increasingly abstract and appear to be free from compulsion. Thus it is imagined that, without direct physical extortion of rent and with the formal freedom to enter into rental contracts of whatever cost and for whatever duration, rent is paid by freely choosing individuals who could choose not to rent if they so wished. As the liberal slogan goes, we are all 'free to choose' where and how to live. ${ }^{13} \mathrm{We}$ are free to choose our standard of subsistence and social participation, as long, of course, as we choose to pay.

The analysis of rent is complicated by the fact that rent has moved into a range of other spaces in contemporary economic life. Businesses today routinely engage in long-term rental of property and equipment, information access, and other platforms, while one-off rental of specialised equipment and machines is standard practice. Alongside this are business practices such as franchising - a payment for access to a brand name, information, suppliers, and so forth, that one would otherwise be unable to access. This diverse range of practices reflects only a fraction of the expansion of rent in recent years. The expansion has been so vast that some observers of this phenomenon have suggested there is a 'becoming-rent of profit', a process whereby many capitalist businesses and investors receive returns for things that look more like rent than profit on enterprise. ${ }^{14}$ Thus businesses have moved into new spaces of rent extraction in which customers often no longer purchase goods outright but instead pay an ongoing subscription for the right of access to software, music, gaming, entertainment, or other services. In these new forms of rent, what remains is a firm line of separation. This is not outright exclusion, but rather a manufactured and carefully managed exclusion which can be overcome only if one is willing and able to pay. This rent can take the form of direct payment of subscription dues or can be paid in the form of provision of

13 Milton Friedman and Rose Friedman, Free to Choose: A Personal Statement (New York: Harcourt, 1980).

14 Carlo Vercellone, 'The Crisis of the Law of Value and the Becoming-rent of Profit,' in Crisis in the Global Economy: Financial Markets, Social Struggles and New Political Scenarios, eds., Andrea Fumagalli and Sandro Mezzadra (New York: Semiotext(e), 2010); Rachel O’Dwyer, 'Spectre of the Commons: Spectrum Regulation in the Communism of Capital,' ephemera: theory and politics in organization 13, no. 3 (2013): 497-526. 
personal information or willingness to submit oneself to advertising, as in the case of 'free' platforms such as Facebook.

This expansion and multiplication of rent into new areas is accompanied by an equally important expansion of those who benefit from rents on property and other assets, that group known classically as rentiers or the rentier class. ${ }^{15}$ This is an expansion not necessarily so much in terms of the number of people who earn income from rent but in the amount of rent that is paid to the rentier class. The rise of rentier capitalism does not automatically solicit opposition to rent, although it clearly does produce the grounds for political contestation or at the very least reflection on the social realities of rent and the privileges of the rentier class. Consequently, there is a well-documented history of the processes of opposition to specific practices of rent and of the notion of rent as such. ${ }^{16}$ These range from the smallest acts of resistance to and refusal of the demands of property owners through to returning privately monopolised property to community, collective, or state ownership. More modest measures include the rent strike, a refusal of rent increases, or a demand for the reduction of rents. Rent strikes may or may not involve calling into question the principle of rent and may simply seek to make rent extortion more 'liveable'.

In Aotearoa New Zealand, the work of political organisations such as Renters United, the Tamaki Housing Group, and the Student Housing Action Group, have objected not only to high rents and poor housing but, beyond this, have made clear the basic violence of the principle of rent. Likewise, government initiatives for rent controls, often arising at the local municipal level, have had a massive impact throughout the world, and generally walk this same tightrope between challenging excessive rents and seeking to combat its basic violence. In Aotearoa New Zealand, the very idea

15 On the rise of the rentier class today, see Peter Frase, Four Futures: Life After Capitalism (London; Verso, 2016); Guy Standing, The Corruption of Capitalism: Why Rentiers Thrive and Work Does Not Pay (London, Biteback, 2017).

16 Resistance to rent in Aotearoa New Zealand has been meticulously documented by Elinor Chisholm, 'Renter Activism in New Zealand, 1916-2016,' Labour History Project Bulletin 68 (2016): 21-27; Individual and Collective Action for Healthy Rental Housing in New Zealand: An Historical and Contemporary Study (PhD, University of Otago, 2016), especially chapters 5-9. 
of rent controls has been met with astonishment and horror by capitalist economists and by lobby groups established to support the interests of landlords such as the New Zealand Property Investors' Federation and the Auckland Property Investors' Association. Through most of the $20^{\text {th }}$ century, Aotearoa New Zealand had legislation enacting what were generally called 'fair rents'. This was passed into law with acts that restricted rents such as the War Legislation Amendment Act of 1916 and the Rent Restriction Act of 1924, both of which were repealed on 3 June 2017.

Today, instead of taking any coherent position on the question of rent, governments generally accept the principle of 'market rents', recognising that such rents will price many out of the market. Consequently, governments provide accommodation supplements for those unable to pay. In Aotearoa New Zealand, these supplements amount to well over $\$ 2$ billion per annum in the form of Accommodation Supplement and Income-Related Rent Subsidies, which are paid to those in rental accommodation and are almost immediately transferred to landlords. ${ }^{17}$ This is a state subsidy that transfers wealth gathered through general taxation to those who own land and benefit from the rent collected on it.

Practices of resistance to rent, whether these are rent strikes organised in the extra-parliamentary sphere or rent controls organised by local or national government, are non-market measures that seek to reduce the violence of uncontrolled rental markets. More often than not, they arise out of concrete, lived understandings of the rental market's inability to provide adequate accommodation. These involve the operationalisation of principles such as the idea that housing is a right, and that a certain size,

17 Ministry of Social Development figures for the second quarter of 2018 place the Accommodation Supplement at \$1,456 million per annum and the Income-Related Rent Subsidy at $\$ 916$ million per annum. Combined, this is $\$ 2,371$ million per annum and constitutes almost all of the commitment to housing expenditure out of $\$ 646.6$ million for the second quarter of 2018. See Ministry of Social Development, Housing Quarterly Report June 2018, https://www.msd.govt.nz/documents/about-msdand-our-work/work-programmes/social-housing/housing-quarterly-report-jun 2018 . pdf. To place these figures in wider context, the Accommodation Supplement and Income-Related Rent Subsidy equate to just over half of the 2017 annual budget operating surplus of $\$ 4.07$ billion. Total core Crown revenue for the New Zealand government in 2017 was $\$ 83.8$ billion. See New Zealand Treasury, 2017 Budget at a Glance. 
quality, and constancy of accommodation is not just desirable but something that all should be able to expect. Likewise, beyond accommodation rentals, such principles also apply equally to the ideas of the right of access to nature, waterways, and beaches, and to things that have been produced in common, such as culture and public spaces.

Traditionally, many economists of the Left directly challenged rent. In the final chapter of his General Theory of Employment, Interest, and Money, John Maynard Keynes outlined some of the 'outstanding faults of the economic society in which we live', notably 'the failure to provide for full employment and its arbitrary and inequitable distribution of wealth. ${ }^{18}$ In this context, Keynes famously advocated for 'the euthanasia of the rentier' and the disappearance of the 'rentier aspect of capitalism'. ${ }^{19}$ Keynes anticipated, or rather hoped, that this euthanasia would be gradual rather than revolutionary, and imagined that this would take place within capitalism. He hardly accounts for the fury that would be unleashed by those who benefit from taking rents from others, and his economic arguments for this euthanasia clearly fail to consider the scarcity that is artificially manufactured by those monopolising land and capital. There are major debates about the extent to which directly challenging the rentier class is a challenge to capitalism. ${ }^{20}$ But perhaps more important is the fact that Keynes, who was ultimately a defender of capitalism, advocated so directly against rent and the rentier class.

Over the past decade, faced by crisis, inequality, and austerity politics, many economists and politicians have returned to Keynes or have renewed their pleas for the importance of his thought, often as a response to the excesses of monetarism and economic liberalism. ${ }^{21}$ Perhaps unsurprisingly, this has very rarely been attached to a serious analysis of rent. Politicians of the ostensible Left in Aotearoa New Zealand often speak in support of

18 John Maynard Keynes, General Theory of Employment, Interest, and Money (London: Macmillan, 1967 [1936]), 372.

19 Keynes, General Theory, 376.

20 Compare, for example, Frase, Four Futures and Standing, The Corruption of Capitalism.

21 See, for example, Robert Skidelsky, Keynes: The Return of the Master (London: Penguin, 2010). 
Keynes and post-Keynesian economics, but they hardly ever say anything about rent, let alone about the proposal for the abolition of rent and the euthanasia of the rentier class. Against this, a genuine return to Keynes would put rent and its abolition clearly back on the political landscape.

\section{Interest}

In the ostensible return of Keynesianism in economic policy over the past decade, it has often been overlooked or underemphasised that Keynes's euthanasia of the rentier involves not just those claiming rents but also those claiming interest on investments. For Keynes this involved the euthanasia of the rentier and 'consequently, the euthanasia of the cumulative oppressive power of the capitalist to exploit the scarcity-value of capital'. ${ }^{22}$ This euthanasia involves doing away with 'the functionless investor', 'the financier', and 'the entrepreneur et hoc genus omne [and all of their kind]'. ${ }^{23}$

The political and moral basis for this abolition follows from the argument that rent is not a reward for work but for the monopolisation of land or other property. In the same way, interest is a reward for the monopolisation of money capital. As Keynes writes: 'Interest to-day rewards no genuine sacrifice, any more than does the rent of land. The owner of capital can obtain interest because capital is scarce, just as the owner of land can obtain rent because it is scarce' ${ }^{24}$ This scarcity is not a natural fact. It is a result of the monopolisation of money in the hands of one group of people, who can then claim interest from those excluded. Keynes sketches a future in which capital is not scarce. He clearly appreciates the skills of planning and foresight on the part of investors. But, as he makes clear, there are many ways of making use of the human skills of planning and oversight that are today rewarded with interest on capital, and these could themselves be recognised as forms of labour. Such planning functions will of course remain in any foreseeable society, and might well expand with increasing

22 Keynes, General Theory, 375-376.

23 Keynes, General Theory, 376.

24 Keynes, General Theory, 376. 
complexity, interconnectedness, and social demands. Whether they are or should be rewarded with interest, however, is a completely different matter.

Alongside the longstanding contestation of rent, there are a range of ancient traditions of refusal and rejection of the principle of interest. Indeed, when seeking to justify the principle of interest, capitalist economists face the difficulty that most indigenous people around the world and most of the classical Western tradition are opposed to the taking of interest. There is, in short, long-standing philosophical, religious, social, and political antipathy to interest. Aristotle, for example, famously distinguished between two means for attaining wealth: one which is 'necessary and honourable' and another 'unnatural, and a mode by which men gain from one another'. ${ }^{25}$ The honourable means is through the management of a household, which for Aristotle is economics proper, while the other is exchange and retail trade. Aristotle decries interest as 'the most hated sort' of retail trade, writing that 'of all the modes of getting wealth this is the most unnatural'. ${ }^{26}$

This kind of disdain for interest-taking and associated practices such as currency conversion also runs through the Biblical tradition. The prohibition on interest is unequivocal in the Qur'an, which stresses that 'Allah has permitted trade and has forbidden interest' and that those who deal in interest or usury 'are the companions of fire; they will abide eternally therein' (2:275). Philosophical and religious prohibitions on interest are of massive historical significance both in the practical world of business and in the writings of Islamic scholars and the medieval scholastics of Europe. Throughout, these writers grappled with this clear and definitive prohibition on interest because it arises not from work or the fertility of land but purely from ownership and exclusion. Interest is money paid by those who do not have it to those who do because they have it.

This is both a question of the scarcity of money and also of the distribution of money such that this scarcity is experienced unevenly. Eugen von Böhm-Bawerk, who is perhaps the greatest economic ideologist in favour of interest, is clear that, of both rent and interest, 'The proximate

25 Aristotle, Politics, in Complete Works, ed. Jonathan Barnes (New Jersey: Princeton University Press, 1984), 1258a40, 1258b1-2.

26 Aristotle, Politics, $1258 \mathrm{~b} 2,1258 \mathrm{~b} 7$. 
cause of both is unequal distribution'. ${ }^{27}$ Inequality is the fundamental basis of interest. Inequality is important at a more general level as well because, without an account of difference, it is impossible to properly understand either economy or society. ${ }^{28}$ Difference in the conditions and prospects of life come out with particular clarity in the case of interest. It should be stressed that this is not a principle that is imposed upon capitalist economics from outside; rather, difference is a formal principle required in order to understand what interest is. Recognition of this was made very clear in the late $17^{\text {th }}$ century by John Locke, who sought to justify the principle of interest and moreover unrestricted rates of interest:

Money is a barren thing, and produces nothing, but by Compact transfers that Profit that was the Reward of one Man's Labour into another Man's Pocket. That which occasions this, is the unequal distribution of Money; which Inequality has the same effect too upon Land, that it has upon Money. ${ }^{29}$

One of the key problems that proponents of interest confront, then, is that interest arises without work. Böhm-Bawerk, for instance, is clear that interest 'arises independently of any personal act of the capitalist. It accrues to him even though he has not moved a finger in creating it'. ${ }^{30}$ The problem is that, being an income that is not a result of work, the principle of interest is in conflict with the meritocratic idea of the equivalence of work and reward and the idea that claims to property are justified in terms of work. This is why in the $18^{\text {th }}$ century the French political economists known as the Physiocrats included beneficiaries of interest among what they called

27 Eugen von Böhm-Bawerk, Capital and Interest, Volume One: History and Critique of Interest Theories (Illinois: Libertarian Press, 1959 [1884]), 28.

28 This is the basic premise of what I call Differential Political Economy, elements of which are articulated in Jones, 'The World of Finance'.

29 John Locke, 'Some Considerations of the Consequences of the Lowering of Interest and Raising the Value of Money,' in Locke on Money, ed. Patrick Hyde Kelly (Oxford: Clarendon, 1991 [1691]), 250. On the place of the 'labour of division' and the idea that differences in wealth are the principle which gives occasion to interest see Campbell Jones 'The Meanings of Work in John Locke,' in History of Economic Rationalities, eds., Jakob Bek-Thomsen et al (Dordrect: Springer, 2017).

30 Böhm-Bawerk, Capital and Interest, 1. 
the 'sterile class' as opposed to the agricultural 'productive class', and $19^{\text {th- }}$ century socialists included traders, financiers, and landlords among the 'parasitic class'. ${ }^{31}$

The politics of interest has promised to return to centre stage in recent years with the rise of finance and eye-watering increases in levels of indebtedness. This has involved massive increases in lending and borrowing, both short- and long-term, in the form of mortgages, personal loans, credit cards, and student loans, and with lending between capitalist firms and the banking sector in efforts to increase 'leverage'. This has been further enabled by legal changes and macroeconomic policy commitments to low interest rates for three decades, something which has been a significant factor in rising house prices.

Even with low interest rates, though, the politics of interest does not disappear but instead takes on another form. This involves increasing levels of lending and borrowing in order to produce the same returns and, with this, associated dynamics such as the increased tendency toward financial crises as a result of overexposure relative to incomes. Beyond this has emerged a specific set of politics associated with the strategies of 'governing by debt'. ${ }^{32}$ This raises a set of profound questions about the nature and limits of social bonds and debts to other people. ${ }^{33}$ Further, this has seen a series of political interventions against banking and finance, from Occupy and proposals for debt strikes and debt jubilees to new strategies for banking regulation. ${ }^{34}$

31 François Quesnay, Tableau économique, eds., and trans., Marguerite Kuczynski and Ronald Meek (London: Palgrave Macmillan, 1972 [1758-1759]); Henri SaintSimon, Selected Writings on Science, Industry and Social Organisation, ed. and trans. Keith Taylor (London: Croom Helm, 1975 [1802-1825]).

32 Maurizio Lazzarato, Governing by Debt, trans. Joshua Jordan (New York: Semiotext(e), 2015).

33 David Graeber, Debt: The First 5,000 Years (New York: Melville, 2014); Miranda Joseph, Debt to Society: Accounting for Life under Capitalism (Minneapolis: University of Minnesota Press, 2014).

34 On debt strike, see, for example, Strike Debt, The Debt Resisters' Operation Manual (Oakland: PM Press, 2014). At the time of making final revisions to this paper (November 2018), the Financial Markets Authority, a generally spineless regulator established in 2011 by Simon Power (then Minister of Justice and Minister 
One of the more interesting scandals in the world of rugby came in April 2017 when renowned All Black Sonny Bill Williams took to the field for the Auckland rugby team, The Blues, with medical tape covering the logos of the Bank of New Zealand that are prominent on the chest and collar of the team shirt. This event attracted considerable media attention, with many expressing bemusement at the meaning of this act. Later, it emerged that Williams's refusal to wear the insignia of the bank was done for principled reasons arising from his religion. Williams had converted to Islam in 2009, and subsequently undertook his Umrah pilgrimage to Mecca and Medina in January 2018. Public response turned to the details of Williams' protest, with media pundits asking about his 'special treatment', first in allowing the taping and then in preparing a shirt for him by specifically removing that one advertisement. ${ }^{35}$ When asked about the taped shirt shortly after the incident, former Minister of Finance, and then Prime Minister of New Zealand, Bill English commented that it was 'hard to understand' why one person might want to act differently from others. ${ }^{36}$ This pretence of

of Commerce, now General Manager of Consumer Banking and Wealth at Westpac Bank) issued a report with the Reserve Bank of New Zealand. This report noted a series of 'gaps' in the New Zealand regulatory environment, implementation by banks of FMA regulations, and questionable practices such as targets for over-thecounter selling of debt to customers not wanting or needing it. See FMA and RBNZ, Bank Conduct and Culture, November 2018, https:/fma.govt.nz/assets/Reports/_ versions/11883/Bank-Conduct-and-Culture-Review.1.pdf. As is to be expected, Mike Hosking, who in this country has a reputation for representing the most outrageously idiotic forces of reaction and bigotry, ran to the defence of the banks against even this most minor slap on the wrist. This master of 'common sense' and ostensible opponent of 'ideology' and 'theory', again managed perfectly to reflect capitalist ideology in its most reduced and simplified form. See Mike Hosking, 'It's Cool to Hate Banks and Oil Companies but They're not Crooked,' New Zealand Herald, November 8, 2018, https://www.nzherald.co.nz/business/news/article.cfm?c_id=3\&objectid=12155952.

35 Questions were also asked about why this came so long after his conversion to Islam and why he did not cover up the massive advertisement for the American finance and insurance company AIG, which, it should be noted, was bailed out in late 2008 by the US federal government to the tune of US $\$ 180$ billion.

36 Stuff, 'Prime Minister Bill English Criticises Sonny Bill Williams' Decision to Cover up Sponsor's Logo,' April 10, 2017, https://www.stuff.co.nz/sport/rugby/superrugby/91394178/Prime-Minister-Bill-English-criticises-Sonny-Bill-Williams-decisionto-cover-up-sponsors-logo?utm_source=dlvr.it\&utm_medium=twitter. Video online at: http://www.radiolive.co.nz/home/video/2017/04/watch-bill-english-on-state- 
incomprehension, which invites audiences to share in astonishment at the traditions and experiences of other people, is not new and was a mark of the rhetorical strategy of the fifth National government of which English was a central part. That government was typified by a strategy of deflection and deflation of politics, organised around a tactics of 'risk management' of anything verging on the political. ${ }^{37}$ Even if it is now delivered with more kindness and good will, this strategy of depoliticisation has been almost perfectly continued by the Labour/New Zealand First coalition that was elected in 2017.

The beneficiaries of interest have always claimed that moral, philosophical, and religious objections to, and prohibitions of, interest are nothing but troublesome meddling. ${ }^{38}$ Armies of capitalist economists have come to their defence, arguing that interest, like other economic practices, is morally neutral or that the real value of things bears no relation to work, but is and should be determined solely by the play of forces between economic actors. They may well then admit that receiving an income in the form of interest is useful to the recipient. And yes, that having more money would certainly be useful for those who have little.

\section{Profit}

Along with rent and interest, there is equally always a politics of profit. This can concern the levels of profit, the locations from which, or the

abuse-of-children-that-sbw-jersey-edgecumbe.html (at 8'21").

37 On the strategies of class war and the efforts to depoliticise alternatives characteristic of that government see Vijay Devadas and Brett Nichols, 'The Meaning of John Key,' New Zealand Journal of Media Studies 13, no. 2 (2012): 18-31 and Jones, 'John Key the Biofinancial Entrepreneur.'

38 That great defender of liberty, Jeremy Bentham, for example, proclaimed in the name of freedom that 'no man of ripe years and of sound mind, acting freely, and with his eyes open, ought to be hindered, with a view to his advantage, from making such bargain, in the way of obtaining money, as he thinks fit, nor, (what is a necessary consequence) anybody hindered from supplying him, upon any terms he thinks proper to accede to.' A Defence of Usury: Shewing the Impolicy of the Present Legal Restraints on the Terms of Pecuniary Bargains, in a Series of Letters to a Friend (Cambridge: Cambridge University Press, 2014 [1787]), 3. 
peoples from whom, profits are extracted, or can extend to the principle of profit as such. The massive and longstanding efforts on the part of capitalist economics and capitalists who take profit must be seen for what they are: as responses and reactions against such criticisms. The rise of the capitalist system of profiteering was accompanied throughout by outrage and astonishment at the levels of profit that come with cooperative and technologically improved labour, and by a more generalised astonishment and outrage at the principle of profit and the efforts to justify it. Recent years have, therefore, seen a return of growing concern over corporate and banking profits, which are always followed quickly by efforts from business leaders and their representatives in the government, media, and the university to defuse this, to normalise the principle of profit, and either to justify profit as such or to argue that, even if profit is troubling, it leads to positive outcomes like job creation and economic growth.

Capitalists, capitalist economics, and the capitalist state have thus sung in unison the virtues of profit and the imagined social benefits of the profit system. Consider, for example, the reassurance offered to business and the public in the speech of former UK Prime Minister David Cameron to the Conservative party conference on 2 October 2013. He placed profit in a chain of other signifiers in an effort to associate and bind them together, reassuring with confidence: 'We know that profit, wealth creation, tax cuts, enterprise . . . these are not dirty, elitist words-they're not the problem . . . they really are the solution'. ${ }^{39}$ This kind of reassurance is not unusual, borrowing, in the UK context, from the language of Thatcher and Thatcherism at the same time as it echoes and connects with the international reassurance and confidence of the capitalist class in their knowledge, as well as the generalisation of a 'we' that is characteristic of recent defences of capitalism. ${ }^{40}$

39 https://www.newstatesman.com/staggers/2013/10/david-camerons-speechconservative-party-conference-2013-full-text. It is perhaps worth noting that Cameron later claimed, on April 11, 2016, that 'Aspiration and wealth creation are not somehow dirty words', in defence of charges against him of tax avoidance and involvement in the Panama papers affair. See https://www.telegraph.co.uk/ news/2016/04/11/david-cameron-says-wealth-is-not-a-dirty-word-following-tax-row/.

40 On the ideology of Cameronism see Richard Seymour, The Meaning of David 
As could be anticipated, this kind of reassurance was immediately contested, not by what was then the Labour party, but more often in the form of public attacks. Later that month, for example, the actor and comedian Russell Brand took up Cameron's statement in an interview with Jeremy Paxman where he said: 'I think the very concept of profit should be hugely reduced. David Cameron said profit isn't a dirty word, I say profit is a filthy word. Because wherever there is profit there is also deficit'. ${ }^{41}$ Brand's formulation could well be improved. We might say, for example, 'where there is profit there is poverty'; or, more accurately, 'where there is profit monopolised by one group at the expense of others, there is poverty'. One year later, Brand released a book entitled Revolution that sought to give more precision and depth to his arguments. ${ }^{42}$ In terms of the standards of university discourse, that book is clearly a failure. But what it did do was draw increased attention to a range of criticisms of capitalism, distribution of profit, and profit itself from scholars such as David Graeber, Noam Chomsky, and Thomas Piketty. ${ }^{43}$

Such thinkers are only the tip of an academic iceberg contesting the allocation of profits and the very idea of profit. This scholarly concern with profit, however, often remains purely academic or is toned down by those interested in knocking politely on progressive policy doors. And it is only sometimes connected with the longstanding Left recognition that wealth is always socially produced and profit is built on a relation between the owners of capital and those that they exploit. These contentions rest behind the classic socialist denunciation of poverty in the midst of wealth. ${ }^{44}$ It is

Cameron (London: Zero, 2010); Christian Fuchs, 'Neoliberalism in Britain: From Thatcherism to Cameronism', Triple C 14, no. 1 (2016): 163-188. On the celebration of hard work by David Cameron, see Jones, 'The Value of Work and the Future of the Left', 144.

41 https://www.youtube.com/watch?v=3YR4CseY9pk.

42 Russell Brand, Revolution (London: Century, 2014).

43 In books including Graeber, Debt: The First 5,000 Years; Noam Chomsky, Profit Over People: Neoliberalism and Global Order (New York: Seven Stories, 1999); Thomas Piketty, Capital in the Twenty-First Century, trans. Arthur Goldhammer (Massachusetts: Harvard University Press, 2014).

44 Among the many formulations of this contradiction see, for example, PierreJoseph Proudhon, What is Property? eds., and trans., Donald Kelley and Bonnie Smith 
also central in motivating the demand for a return to workers of the wealth that they have produced. Redistribution, it should be remembered, can be claimed in the name of generosity or mercy for the poor, but can also be made directly in the name of a principle of meritocracy that seeks the return of wealth to those who have in fact produced it and from whom it was extorted. ${ }^{45}$

Contestation over the rate of profit often takes the form of a debate over what is known as the labour income share (LIS). This is the portion of economic activity in a sector or a national economy that goes to wage and salary earners as opposed to the owners of capital. One of the things that is very clear from economic data is that the percentage of national income accruing to labour has fallen in most advanced capitalist economies since at least the $1980 \mathrm{~s} .{ }^{46}$ This is during a time of considerable increases in productivity per worker, which means that both the share of the total and most of these gains in worker productivity over this period have been secured by owners of capital rather than by workers.

In Aotearoa New Zealand, the data on LIS are consistent with this international trend. ${ }^{47}$ The immediate post-war period saw a rise in LIS from

(Cambridge: Cambridge University Press, 1994 [1840]).

45 This applies from the smallest, local redistributions of wealth to the global redistribution of wealth in the light of colonial theft. The meritocratic case is put well by Frantz Fanon: 'So when we hear the head of a European state declare with his hand on his heart that he must come to the help of the poor under-developed people, we do not tremble with gratitude. We say to ourselves: "It's a just reparation which will be paid to us". Nor will we acquiesce in the help for under-developed countries being a programme of "sisters of charity". This help should be the ratification of a double realization: the realization by the colonized people that it is their due, and the realization by the capitalist powers that in fact they must pay'. Fanon, The Wretched of the Earth, trans. Constance Farrington (London: Penguin, 2001 [1961]), 81.

46 International Labour Organization and Organization for Economic Cooperation and Development, The Labour Share in G20 Economies (2015), https://www.oecd.org/ g20/topics/employment-and-social-policy/The-Labour-Share-in-G20-Economies.pdf; International Labour Organization, Global Wage Report 2016/2017: Wage Inequality in the Workplace (Geneva: International Labour Organization, 2016).

47 Bill Rosenberg, 'A Brief History of Labour's Share of Income in New Zealand 1939-2016,' in Transforming Workplace Relations in New Zealand 1976-2016, eds., Gordon Anderson et al (Wellington: Victoria University Press, 2017). 
52 percent in 1947 to 66 percent in $1976 .{ }^{48}$ However, the 32 years from 1978 to 2010 saw LIS fall from 64.6 percent to 56.3 percent, a fall of 8.5 percent in absolute terms. ${ }^{49}$ Over the past decade this level has been relatively stable, with a slight fall between 2010 and 2016 to 55.5 percent in $2016 .^{50}$ The longrun fall in LIS in Aotearoa New Zealand has taken place in a context of constantly rising labour productivity. From the late 1970s to 2010, labour productivity rose on average by 2.2 percent per annum while real wages grew at 1.7 percent. $^{51}$ Constantly rising labour productivity resulted in almost doubling output per labour hour between 1987 and 2015.52

While the differences in LIS in percentage terms and the discrepancy between labour productivity and wage growth may appear small, when aggregated to the level of the economy as a whole they produce significant results. With a peak of LIS in 1981 and a major fall following the June 1982 price- and wage-freeze, 'the labour share of income fell from approximately $60 \%$ of income in the early 1980 s to $46 \%$ in 2002 ' ${ }^{33}$ The aggregate result of this fall in LIS between 1982 and 2002 was enormous. It has been estimated that

In current dollar terms [2015], that is a loss of about $\$ 19$ bn per year, or $\$ 10,000$ per wage-earner per year. The present value of the loss over that period is estimated at between $\$ 660 \mathrm{bn}$ (at a discount rate equivalent to

48 Brian Easton, Income Distribution in New Zealand, New Zealand Institute of Economic Research, Research Paper no. 28, 1983.

49 Huon Fraser, The Labour Income Share in New Zealand: An Update. New Zealand Productivity Commission Research Note 2018/1 (Wellington: New Zealand Productivity Commission, 2018), 3.

50 Fraser, The Labour Income Share in New Zealand, 5.

51 Paul Conway, Lisa Meehan, and Dean Parham, Who Benefits from Productivity Growth? The Labour Income Share in New Zealand, New Zealand Productivity Commission Working Paper 2015/1 (Wellington: New Zealand Productivity Commission, 2015), 18.

52 Statistics New Zealand, 'Labour Productivity,' http://archive.stats.govt.nz/ browse_for_stats/snapshots-of-nz/nz-progress-indicators/Home/Economic/labourproductivity.aspx.

53 Bill Rosenberg, 'Wages and Inequality,' Policy Quarterly 11, no. 1 (2015): 66. 
investment in term deposits) and $\$ 1,200 \mathrm{bn}$ (at a discount rate equivalent to paying off a mortgage)..$^{54}$

What this means is that during the period 1982-2002 capital received what can be estimated as approximately $\$ 1$ trillion more than it would have received had that LIS remained at the level it was in 1981. This would mean that working people and their families would have received $\$ 1$ trillion more than they would have otherwise earned over those two decades. A trillion dollars is $\$ 1,000,000,000,000$. Any casual underpayment or informal 'wage theft' from individual workers pales in comparison to this figure. And this is not the total amount of income earned by capital at the expense of workers over that period; it is only the increase that resulted from workers losing a quarter of the income they received prior to 1982.

Perhaps the most surprising aspect of this extortion of wealth from working people, whether in the form of normal profits, or of 'surplus profits' above the normal rate of profit, is the fact that this hardly registers on the political terrain. ${ }^{55}$ Almost entirely across the political spectrum of parliamentary politics, this rate of profit and surplus profit has by and large gone unremarked or has been treated as unremarkable. Notable exceptions such as Bill Rosenberg, Chief Economist at the New Zealand Council of Trade Unions, have raised the issue, but this has been dismissed by parties of the Right and has effectively been ignored by parties claiming to be of the Left. ${ }^{56}$

Leading the depoliticisation of the politics of profit has been recourse to ideas from capitalist economics and taking seriously the commentary of right-wing think tanks and organisations such as the New Zealand

54 Rosenberg, 'Wages and Inequality,' 63-72.

55 To avoid confusion, it should be noted that 'surplus profit' is being used here in the technical sense, not to refer to surplus-value as such but rather to exceptional or surplus rates of profit above the norm. Surplus profit 'consists precisely in the excess of individual profit over and above the average profit', Marx, Capital, Volume Three, 782.

56 https:/www.interest.co.nz/news/89552/economist-bill-rosenberg-details-howlow-and-middle-income-wages-have-been-hollowed-out; https://www.union.org. nz/workers-out-of-pocket-11500-a-year-as-a-result-of-decades-of-poor-governmentpolicy/; https://www.radionz.co.nz/news/business/354167/workers-fail-to-get-theirfair-share-of-economic-pie. 
Productivity Commission. The latter is perhaps the most important ideological apparatus for protecting the interests of those that benefit from profit and in particular from high rates of profit. In this, the Productivity Commission, which is a Crown organisation directly responsible to the Minister of Finance, has noticed the reality of a falling LIS, but has portrayed it as following a process that is by and large apolitical and outside of political control. They are fully aware of the long-term fall in LIS over the past 40 years; their own figures were cited above. But the commission pleads neutrality and assumes a pretence of objectivity regarding LIS, reducing any judgements others make to mere 'perspective'. It claims that it 'avoids judgement about the optimal level of the LIS or whether given changes in the LIS are socially beneficial or not. Balancing these considerations depends on the situation and is partly a matter of preference. ${ }^{57}$ In its second major report on LIS, the Commission claimswhile later contradicting themselves on this point - that its research in the area 'does not give any insights into the reasons that real wages have fallen behind labour productivity, nor what an appropriate LIS might be'..$^{58}$

In a certain sense, the side on which one stands on the question of LIS does depend on perspective. But this is only in the sense that one must ultimately take the perspective of either workers, who have lost their share, or the investors of capital, whose share has increased. Needless to say, the Productivity Commission has not shed many tears for the plight of

57 Conway et al, Who Benefits from Productivity Growth? 4. This quote is immediately followed by a bizarre strategy that seeks to lead the reader off track by constructing a binary choice, and in doing so implying an inverse correlation between LIS and productivity growth. Thus, the rhetorical question: 'For example, would New Zealanders prefer to participate in an economy where real wages are increasing strongly but the LIS is falling because productivity growth is even faster, or an economy with weak growth in real wages so that LIS is more constant?' This insinuation is premised on the idea that paying higher wages (i.e. sharing profits) will inevitably harm growth, an insipid prejudice of many economists that is routinely offered without any evidence. Against this, it should be recalled that the International Monetary Fund has emphasised not only the social costs of inequality, but that inequality is also destabilising and damages economic growth because of restraint of income. See Era Dabla-Norris et al., Causes and Consequences of Income Inequality: A Global Perspective (International Monetary Fund, 2015).

58 Fraser, The Labour Income Share in New Zealand: An Update, 9. 
workers, and its analysis has done a great deal to naturalise the process of a falling LIS and to sidestep consideration of the prospect that the relation between workers and capital might be a relation of wealth extraction. This depoliticisation can also be seen in their explanations of the fall in LIS. Their first explanation is technology, which in itself and outside the context of the politics of the application of technology and the resultant returns to workers, is no explanation whatsoever of a falling LIS. They also mention the rise of low-paid, precarious service work, but the rise of this kind of work absent an analysis of bargaining power does little to explain the fall of income share. They evoke globalisation, which is certainly a contributing factor with international labour arbitrage destroying protections of workers in previously privileged regions. But, again, globalisation is treated outside of any serious analysis of international differences in the conditions of labour. Indeed, the commission attempts to sidestep entirely the key issues, which, as has been clearly identified by serious research in this area, are the financialisation of the economy and the politics of welfare-state retrenchment and market deregulation. ${ }^{59}$

The proposed solutions of the Productivity Commission also miss the point. They recommend education as a solution, arguing it will increase productivity. While education can certainly increase productivity, the problem which is reflected in the evidence right in front of them is the fact that productivity growth does not in any automatic way lead to increased LIS. Increasing productivity simply increases the amount that is produced. It in no way guarantees who will be the recipient of that increase.

59 See, for example, the special issue 'Financialisation, Income Distribution and Crisis', Cambridge Journal of Economics 39, no. 3 (2015): 867-986; Engelbert Stockhammer, 'Determinants of the Wage Share: A Panel Analysis of Advanced and Developing Economies', British Journal of Industrial Relations 55, no. 1 (2015): 3-33; Eckhard Hein et al., 'Financialization and Distribution from a Kaleckian Perspective: The United States, the United Kingdom and Sweden Compared - Before and After the Crisis,' International Journal of Political Economy 46 (2017) 233-266. Rosenberg cites a 2013 report by the International Labour Organisation which identifies financialisation ( 46 percent) and falling government spending ( 25 percent) as the key determinant of falling LIS. Rosenberg, 'A Brief History of Labour's Share of Income in New Zealand 1939-2016,' 80. See International Labour Organisation, Global Wage Report 2012/13: Wages and Equitable Growth (Geneva: International Labour Organisation, 2013). 
Increased productivity thus only potentially produces the possibility of better conditions for workers; whether that will eventuate is a matter of the capital-relation, the relation between capital and its prey. ${ }^{60}$ As the history of LIS shows, the distribution of the income that any economy produces is not a simple matter of how much there is. Distribution of income follows no magical laws of its own; it is first and foremost a question of class struggle. ${ }^{61}$

Even if it makes a certain kind of sense to most people that work deserves a reward in the form of wages, considerable conjuring has to be done to persuade people that the owners of capital deserve to receive profits simply because they have capital. This problem echoes the related conjuring trick performed by owners of land or other assets in their efforts to justify their receipt of rent, and by owners of money to justify the fact that they are paid interest. Often it is claimed that owners of capital have foregone enjoying their money in other ways, but this by itself explains nothing as to why owners of businesses are paid for the work of others, and that their rewards increase in proportion to the productivity of their workers. It is also claimed that profit is a return for risk, which is only a partial explanation and only really explains returns on the most speculative ventures. For the most part, powerful capitalist enterprises take little or no risk, and the bestmanaged undertake extensive planning, insurance, and risk-management strategies to avoid even the slightest unplanned contingency. The more honest explanation is that profit is a social convention; it is paid because it is expected and permitted. Investors of capital scan the landscape for investment opportunities in those places where the returns will be best. Across the entire face of the planet, capital seeks out those places where it will be rewarded for the fact that it is missing there.

The owners of capital tell other fantastic tales, among which perhaps the most incredible is of the role capital is purported to play in job creation. This is first of all a direct inversion of the relation of need between capital and labour. Capital needs to have people in jobs working as wage labourers,

60 This much at least is clear: 'Wages are determined through the antagonistic struggle between capitalist and worker'. Karl Marx, Economic and Philosophical Manuscripts of 1844, ed. Dirk Struik, trans. Martin Milligan (New York: International Publishers, 1964 [1932]), 65.

61 Marx, Capital, Volume Three, Chap. 51. 
and so every job created by capital is an expansion of the prospects for capital accumulation. Further, the idea of job creation says nothing about the quality of such jobs, whether these are fulfilling and valuable or are precarious, dangerous, and dehumanising. The idea of job creation as a generalised good does nothing for the prospect of creating prosperity outside of paid employment, or of recognising the value of work that is done outside of paid employment.

Often it is imagined that profits arise due to the effort, hardship, skill, or genius of the owners of capital. This is almost always invented after the fact. It is a retroactive speculation regarding the relation between effort and reward, and generally totally disregards the actual level of skill possessed by the capitalist. The imagination of the greatness of the capitalist is simply assumed to explain the magnitude of profit as meritorious. But the return on capital is categorically distinct from the return on labour. The 'work' of extracting a reward from capital and the rates of return on capital are absolutely not the same as work. This was well known by Adam Smith, who clearly distinguished the principles and the concept of profit from the activity of labour. He was aware of how they might be confused, but was clear of their ineradicable difference:

The profits of stock, it may perhaps be thought, are only a different name for the wages of a particular sort of labour, the labour of inspection and direction. They are, however, altogether different, are regulated by quite different principles, and bear no proportion to the quantity, and hardship, or the ingenuity of this supposed labour of inspection and direction. ${ }^{62}$

Profit rates are secured in relation to the size of the capital invested and the expected and accepted rates of return, rather than any actual work on the part of the owners of capital. They are established by the social expectation that those with wealth should be paid a return on their wealth because they have it. Of course, capitalists are always present in one form or another in capitalist enterprise, and their presence and exertions to extract profit can demonstrably impact the profitability of enterprise. For the capitalist and

62 Adam Smith, The Wealth of Nations, ed. Andrew Skinner (London: Penguin, [1776]), 151. 
those who emphasise their involvement in production, it is therefore quite logical for the capitalist to appear to be the source of profit. The problem, and the thing that the capitalist, capitalist economics, and the capitalist state must always mystify, is that wealth is not produced by capital; it is produced by the work of other people, those who work directly for capital in waged employment or who create the conditions of possibility of capitalist production. This involves not only those immediately present in the moment of paid labour, but most vitally all of those involved in social reproduction, in caring for and making the paid worker possible, in giving birth to and raising children. The source of profit is the work of others, and this depends on a massive social division of labour, the ownership of assets, the riches of nature, and the overall historical process of social development. Just as rent comes from those excluded from access, and interest is tribute paid by those lacking money, the source of profit is the work of others, from which capital lives as a parasite.

\section{Abolition}

Rent, interest, and profit are social relationships that each involve their own specific dynamics and produce their own forms of contestation. Capitalist economics is insistent in its effort to naturalise and normalise the relations of rent, interest, and profit, and, with this, to present as unnatural or abnormal any social relations not assuming these as unquestionable premises. It is also a telling indictment of the parliamentary 'Left' that it has so thoroughly accepted these principles as basic and inevitable, leaving it without a meaningful politics. Still, while there is nothing surprising about the Left accepting the basic coordinates of the Right, there is equally nothing inevitable about it.

When, in May 2018, John McDonnell, MP and shadow chancellor of the exchequer of the UK, joked on BBC television that 'fomenting the overthrow of capitalism' was no longer his hobby but his job, perhaps most important was his clarification that he saw no difference between 
transforming the economy and overthrowing capitalism. ${ }^{63}$ While some 'beautiful souls' may find actual intervention in concrete economic matters too far away from confronting and refusing capitalism, my argument here is that concrete intervention in mundane matters such as tax, work, rent, interest, and profit gives flesh to what it means to directly confront and overthrow something otherwise so overwhelmingly massive as capitalism. ${ }^{64}$

Nothing in this should be taken as reformist or as too modest in ambition. Let us be clear, what is proposed here is not simply a reduction in rates of rent, interest, and profit. One does not face up to a cancer by asking if it can be reduced but by removing it. This involves both immediate steps and a long-term strategic horizon. And it involves acknowledgement that removal of the cancerous part will cause some discomfort and pain to the part that is being removed and, in the short term, to the whole body. This involves insisting that rent, interest, and profit are outside of and in conflict with other very important senses of what is valuable, and what and who deserves to live and how. Rebuilding the Left requires being clear about an alternative set of values and the place of care and love for each other and the environment. ${ }^{65}$ But, if this is to be anything other than sentimentality and photo opportunities, then it needs to be accompanied by some hard-nosed economics and committed political organisation. These must be done not with the motivation of making capitalism less insufferable, but by directly and unflinchingly confronting the capitalist class, capitalist economics, the capitalist state, and capitalist ideology.

Doing this involves not adding caring sentiment to a brutal and heartless system that by its very logic is premised on the leveraging of maximum advantage out of unequal distribution of access to our common wealth. Rent, interest, and profit each seek to produce a quite specific

63 BBC News, 'John McDonnell Says Overthrowing Capitalism is His Job,' May 20, 2018, https://www.bbc.com/news/av/uk-politics-44189922/john-mcdonnell-saysoverthrowing-capitalism-is-his-job.

64 Against such beautiful souls, on the need to take back the economy, the need for a wealth tax, and why and how to read capital in the $21^{\text {st }}$ century, see Campbell Jones, 'How to Read Capital in the Twenty-First Century,' Crisis and Critique 3, no. 3 (2016): 141-165.

65 This side of the case is very well made by Harris, The New Zealand Project. 
'world' with a definite arrangement of things and the relations between them. The beneficiaries of rent, interest, and profit, who are awarded a tribute for the fact that they already have wealth, have a lot invested in that world and in making that world look like the best of all possible worlds.

While it may have a negative connotation, abolition as such is far from a purely negative act. Abolition involves moving past and beyond a present obstacle, an obstacle that can later be looked back upon with amazement or as a historical curiosity. The formal abolition of slavery and the defence against its return, for instance, is clearly a positive act, and one that must be constantly repeated. Likewise, the progressive abolition of the right to monopolise land, money, and capital at the expense of our fellow human beings is not a restriction but an increase of human freedom. ${ }^{66}$

A Left can be said to meaningfully exist to the extent that it has a clear programme and prospect for a counter-future, a vision of the future that breaks with the normal parameters of what is taken to be possible. In the traditional breakdown of modern parliamentary democracy, those who sit on the Right of the king seek to preserve order while those who sit on the Left propose to challenge it. Whatever one imagines about oneself, to be on the Left means to have a vision of a counter-future and the will to effect it. By this measure, to the extent that self-identified 'Left' politics limits itself to the most minor efforts to manage the contradictions of capitalism rather than to overcome them, almost all of established parliamentary politics in this country sits on the Right of capital.

To propose a counter-future is not to imagine the magic of a future that could never be. It is to demand something exceptional to the situation that is concretely possible within that situation and is applicable across that situation. These proposals are therefore immanently realistic: the doubling

66 'From the standpoint of a higher socio-economic formation, the private property of particular individuals in the earth will appear just as absurd as the private property of one man in other men. Even an entire society, a nation, or all simultaneously existing societies taken together, are not the owners of the earth. They are simply its possessors, its beneficiaries, and have to bequeath it in an improved state to succeeding generations'. Marx, Capital, Volume Three, 911. Note that Marx here does not assume a historical evolutionary schema, but rather advances a principle from which socioeconomic formations can be judged, and according to which the one which exists today can and should be measured as profoundly impoverished. 
of wages with no increase of hours; the reduction of the return to capital without capital flight; the severe and direct intervention against speculative capital through financial transactions, capital, and wealth taxes; and the radical reduction of rent by regionally managed rent caps and deflation of land values to curb excessive expectations of returns. All of these, however, are merely interim measures. But, in preparing for the abolition of rent, interest, and profit, we will need to explain, patiently, again and again, why these practices are unjust and should be consigned to the dustbin of history. 